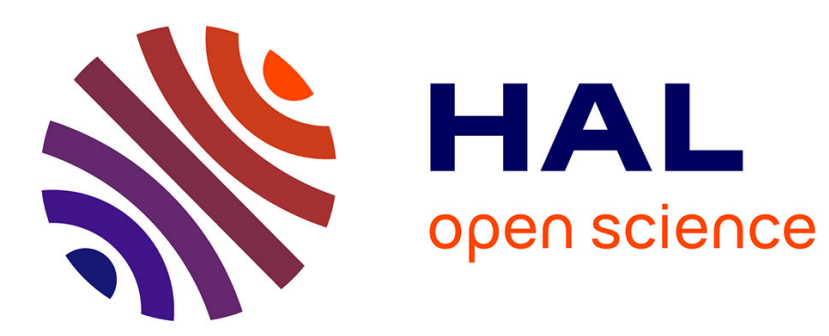

\title{
Effects of salinity on sublethal toxicity of atrazine to mummichog () larvae
}

Marie-Gil Fortin, Catherine M. Couillard, Jocelyne Pellerin, Michel Lebeuf

\section{To cite this version:}

Marie-Gil Fortin, Catherine M. Couillard, Jocelyne Pellerin, Michel Lebeuf. Effects of salinity on sublethal toxicity of atrazine to mummichog () larvae. Marine Environmental Research, 2008, 65 (2), pp.158. 10.1016/j.marenvres.2007.09.007 . hal-00562993

\section{HAL Id: hal-00562993 https://hal.science/hal-00562993}

Submitted on 4 Feb 2011

HAL is a multi-disciplinary open access archive for the deposit and dissemination of scientific research documents, whether they are published or not. The documents may come from teaching and research institutions in France or abroad, or from public or private research centers.
L'archive ouverte pluridisciplinaire HAL, est destinée au dépôt et à la diffusion de documents scientifiques de niveau recherche, publiés ou non, émanant des établissements d'enseignement et de recherche français ou étrangers, des laboratoires publics ou privés. 


\section{Accepted Manuscript}

Effects of salinity on sublethal toxicity of atrazine to mummichog (Fundulus heteroclitus) larvae

Marie-Gil Fortin, Catherine M. Couillard, Jocelyne Pellerin, Michel Lebeuf

PII: S0141-1136(07)00126-2

DOI: 10.1016/j.marenvres.2007.09.007

Reference: MERE 3147

To appear in: Marine Environmental Research

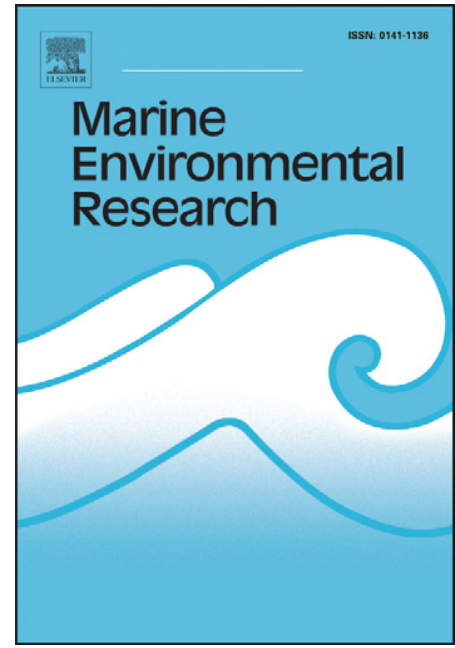

Received Date: $\quad 23$ September 2006

Revised Date: $\quad 10$ June 2007

Accepted Date: $\quad 30$ September 2007

Please cite this article as: Fortin, M-G., Couillard, C.M., Pellerin, J., Lebeuf, M., Effects of salinity on sublethal toxicity of atrazine to mummichog (Fundulus heteroclitus) larvae, Marine Environmental Research (2007), doi: 10.1016/j.marenvres.2007.09.007

This is a PDF file of an unedited manuscript that has been accepted for publication. As a service to our customers we are providing this early version of the manuscript. The manuscript will undergo copyediting, typesetting, and review of the resulting proof before it is published in its final form. Please note that during the production process errors may be discovered which could affect the content, and all legal disclaimers that apply to the journal pertain. 


\section{Effects of salinity on sublethal toxicity of atrazine to mummichog (Fundulus \\ heteroclitus) larvae}

Marie-Gil Fortin $^{a}$, Catherine M. Couillard ${ }^{\text {b,* }}$, Jocelyne Pellerin ${ }^{a}$, Michel Lebeuf ${ }^{b}$

${ }^{a}$ ISMER, Université du Québec à Rimouski, 300 Allée des Ursulines, P.O. Box. 3300, Rimouski, Quebec, Canada, G5L 3A1.

${ }^{b}$ Department of Fisheries and Oceans, Maurice Lamontagne Institute, P.O. Box 1000, 850 Route de la Mer, Mont-Joli, Quebec, Canada, G5H 3ZA.

\section{Abstract}

In coastal marshes, fish larvae may be exposed simultaneously to extreme salinities and to atrazine, a widely used herbicide. To assess the effects of salinity on the toxicity of atrazine, newly-hatched mummichog (Fundulus heteroclitus) were exposed to atrazine $(0,5,50$ and $500 \mu \mathrm{g} / \mathrm{L})$ at three salinities (3, 15 and $35 \mathrm{PSU})$. Whole body cortisol was measured after $24 \mathrm{~h}$. Body length, condition factor, whole body proteins, lipids, residual masses and water contents were assessed after $96 \mathrm{~h}$. Significants effects were found for both condition factor and water content. Condition factors were lower at salinity 3 and 35 compared to near isoosmotic salinity, 15 PSU. In addition, atrazine decreased condition factor at $500 \mu \mathrm{g} / \mathrm{L}$. Reduction in condition was likely due to retardation in axial growth since body length, percentages of proteins or lipids were not affected. In the absence of atrazine, salinity had no effect on the prevalence of dehydrated ( $\leq 81 \%$ water) or hyperhydrated ( $\geq 85 \%$ water) larvae. In larvae exposed to atrazine, the

\footnotetext{
* Corresponding author. Tel.:(418) 775-0681; fax: (418) 775-0718. E-mail address: CouillardC@dfo-mpo.gc.ca (C.M. Couillard).
} 
prevalence of hyperhydrated larvae increased at $3 \mathrm{PSU}$ and $5 \mu \mathrm{g} / \mathrm{L}$ atrazine and that of dehydrated larvae increased at 15 and 35 PSU and $\geq 5 \mu \mathrm{g} / \mathrm{L}$ atrazine. Severity of dehydratation increased with atrazine concentration at salinity 35 PSU. Thus, a short term exposure to environmentally realistic concentrations of atrazine affects osmotic control in mummichog larvae with possible effects on buoyancy, survival and recruitment.

Keywords: Fundulus heteroclitus; Larval bioassay; Atrazine; Salinity; Condition; Cortisol; Water content;

\section{Introduction}

Atrazine (2-chloro-4-ethylamino-6-isopropyl-amino-s-triazine) is one of the most widely used herbicides in North America for the control of weeds and grasses in corn, sorghum and sugarcane. Runoff from agricultural fields is the main source of atrazine to aquatic ecosystems. The highest atrazine concentrations in surface water generally occur in pulses following rain events after herbicide application, with spikes lasting up to several days. In North America, atrazine concentrations up to $108 \mu \mathrm{g} / \mathrm{L}$ have been reported in rivers (USEPA, 2002). Estuaries and coastal marshes are vulnerable to atrazine contamination because they receive waters carrying agricultural pesticides from upland sources (de Lorenzo et al., 2001). Atrazine has been detected in estuarine and coastal waters of the eastern coast of North America at concentrations as high as $30 \mu \mathrm{g} / \mathrm{L}$ in Chesapeake bay (USEPA, 2002).

Several recent laboratory studies have shown that environmentally realistic concentrations of atrazine cause significant toxic effects to fish. For example, low concentrations of atrazine 
$(1 \mu \mathrm{g} / \mathrm{L})$ altered olfactory-mediated endocrine function in male Atlantic salmon (Salmo salar) (Moore and Lower, 2001). At $100 \mu \mathrm{g} / \mathrm{L}$, atrazine altered $\mathrm{Na}^{+} \mathrm{K}^{+}$ATPase activity in common carp (Cyprinus carpio) held in fresh water, indicating osmoregulatory disturbances (Hanke et al., 1983). In addition, in vitro studies in fish have shown that atrazine may affect the secretion of cortisol, involved in osmoregulation and stress response (Bisson and Hontela, 2002).

Studies on the interaction of salinity with atrazine toxicity in fish are scarce. Pre-exposure of Atlantic salmon smolts to atrazine at $\geq 1 \mu \mathrm{g} / \mathrm{L}$ in fresh water caused mortalities (14-43\%) after a sea water challenge with alteration of $\mathrm{Na}^{+} \mathrm{K}^{+}$ATPase activity at $\geq 2 \mu \mathrm{g} / \mathrm{L}$ (Waring and Moore, 2004). Acute lethal toxicity of atrazine on larval sheepshead minnow (Cyprinodon variegatus) increased eight fold with salinity increasing from 5 to 25 PSU (Hall et al., 1994). To our knowledge, the impact of salinity on the sublethal toxicity of atrazine to marine fish species has never been studied.

The euryhaline teleost fish Fundulus heteroclitus, or mummichog, has been used as model species to investigate osmoregulatory and toxicological responses (Hall and Anderson, 1995 and references therein; Marshall et al., 1999). Mummichog live in estuaries and coastal marshes and are broadly distributed along the eastern coast of North America (Joseph and Saksena, 1966). The capacity to osmoregulate is necessary for this species. They repeatedly move from tidal margin shallows, where salinity is low (mimimum reported for mummichog=0.4 PSU) to deeper parts of the estuary during ebb tides, where salinity is high (maximum reported for mummichog=35 PSU) (Griffith, 1974). In waters differing from isosmotic salinity (ie, 1012 PSU for mummichog), compensatory mechanisms (e.g., drinking, urinating, active influx or outflux via ion channels) maintain water and ion concentrations at a constant level (Varsamos et al., 2005). Given that atrazine is used as a pre-emergence herbicide in early spring, when 
mummichog spawn, larvae could be exposed simultaneously to contaminated water and extreme salinities (Joseph and Saksena, 1966; Waring and Moore, 2004).

Early developmental stages are considered to be one of the most sensitive stages in the fish life cycle to the toxic effects of chemical contaminants (Weis and Weis, 1987). Short-term sublethal effects on growth, behaviour or osmotic control may affect the survival of these critical stages and impact recruitment (Houde, 1987, 1989; Sclafani et al., 1997; Alvarez and Fuiman, 2005). For example, loss of osmotic control altering water content may influence larval density and buoyancy. The vertical position of larvae in the water column affects their patterns of drift and their interactions with preys or predators. Thus, a temporary loss of osmotic control in fish larvae may increase their susceptibility to predation or impair their feeding abilities (Sclafani et al., 1997). Disruption of normal cortisol secretion in early life stages may also affect their survival by reducing the ability to cope with acute stressful situations and by inducing adverse secondary effects on osmoregulation, growth, development and immune function (Benguira et al., 2002; Gravel et al., 2005; Kennedy and Farrell, 2005).

This study investigates the effects of salinity on sublethal atrazine toxicity for mummichog larvae. This information is needed to assess the risk associated with the presence of atrazine in coastal and estuarine fish spawning grounds. Suborganismal and organismal responses that have been linked to population responses are examined. Larval body mass and length, proteins and lipids contents are measured to assess effects on larval condition. Water content is also assessed as an indicator of loss of osmotic control. In addition, cortisol content is determined since this hormone is involved in osmoregulation and stress.

\section{Materials and methods}




\subsection{Water}

Filtered (pore size of $0.2 \mu \mathrm{m}$ ) natural seawater (St. Lawrence Estuary, Mont-Joli, QC, Canada, salinities ranging from 20 to $25 \mathrm{PSU}$ ) was diluted with Millipore water to obtain salinities 3 and 15 PSU. The test water with the highest salinity (35 PSU) was prepared by diluting hypersaline brine with Millipore water. Hypersaline brine was obtained as remaining liquid of partially frozen filtered natural seawater at -10 to $-20^{\circ} \mathrm{C}$.

\subsection{Source of chemicals and preparation of stock solutions}

Atrazine (100\% purity) and desethylatrazine (99.2\% purity) standard solutions used for chemical analysis were supplied by AccuStandards Inc. (New Haven, CT, USA). All gaschromatography-grade solvents used for chemicals analyses were provided by EM Science (Gibbstown, NJ, USA). The atrazine powder (99.9\% purity, lot LB16929) used in the toxicity tests was provided by Supelco (Bellefonte, PA, USA). Acetone (99.9\% purity, pesticide free) was obtained from EMD Chemicals Inc. (Gibbstown, NJ, USA).

Atrazine was first dissolved in acetone $(100 \mathrm{mg}$ atrazine $/ 10 \mathrm{~mL}$ acetone). A volume of $100 \mu \mathrm{L}$ of this solution was added to $1 \mathrm{~L}$ of filtered seawater of each salinity to achieve three salinity-adjusted atrazine stock solutions of $1000 \mu \mathrm{g} / \mathrm{L}$. Therefore, solvent concentration in the exposure media could never exceed $100 \mu \mathrm{L} / \mathrm{L}$ according to recommendations of the American Society for Testing and Materials (ASTM, 2004). Stock solutions were made on the first day of the experiment and kept in the dark at $4^{\circ} \mathrm{C}$ until the end of the experiment, 3 days later. 


\subsection{Source of mummichog larvae}

Adult mummichog were captured at a reference site, Horton's Creek, NB, Canada, and brought alive to the Maurice Lamontagne Institute, Mont-Joli, QC, Canada, where they were kept in a 420-L living stream aquarium with flowing seawater. Filtered ambient seawater (salinity 26 PSU) was provided by the Maurice Lamontagne Institute marine laboratory system, located on the south shore of the St. Lawrence Estuary, QC. Previous measurements of PCBs, polychlorinated dibenzodioxins and dibenzofurans in the liver of mummichog captured at Horton's Creek indicated low contamination and supported the selection of this site as a reference (Couillard and Nellis, 1999). To induce gonadal maturation, the water temperature was raised progressively from $10^{\circ} \mathrm{C}$ to $20^{\circ} \mathrm{C}$, and a photoperiod of 14-h light: 10 -h dark was maintained (Boyd and Simmonds, 1974; Couillard, 2002). The fish were fed ad libitum twice daily with pelleted cichlid food (Nutrafin ${ }^{\circledR}$, Rolf C. Hagen Inc., Montreal, QC, Canada) supplemented with dried shrimps.

Approximately $1-6 \mathrm{~h}$ after natural fertilization, eggs were collected on spawning substrates. Eggs were incubated outside of water on damp filter paper (moistened with water at salinity $15 \mathrm{PSU}$ ) in Petri dish at $22^{\circ} \mathrm{C}$. Hatching was induced by immersion in water of salinity 15 PSU on day 11.

\subsection{Bioassays}


A factorial design consisting of three salinities (3, 15 and 35 PSU) and four nominal concentrations of atrazine $(0,5,50$ and $500 \mu \mathrm{g} / \mathrm{L})$ crossed for a total of twelve treatments. Salinities were chosen to represent a near isosmotic salinity (15 PSU) and two salinities (3 and $35 \mathrm{PSU}$ ) representing the extreme range to which mummichog are exposed in field conditions (Griffith, 1974; Varsamos et al., 2005). A short-term, acute -exposure period (96-h) was selected to represent field exposure conditions.

Specific volumes of salinity-adjusted atrazine stock solutions were added to filtered and aerated water ( $>95 \%$ dissolved oxygen) of each salinity to achieve the desired concentrations. Larvae were exposed in 250-mL glass Mason jars containing $210 \mathrm{~mL}$ of test solution. Newlyhatched larvae were randomly assigned to each jar. Larvae were incubated at $20^{\circ} \mathrm{C}$ under fluorescent light on a 12:12 light: dark cycle and were not fed during the experiment.

Exposure lasted 96 h (4 replicates of 10 larvae each) with daily renewal of the solutions for assessment of larval condition and water content. For each treatment, solutions were renewed with solutions with the same salinity and the same concentration of atrazine throughout the exposure period. It was not necessary to feed the larvae since they rely on their yolk sac in the first 4 days after hatching. Dissolved oxygen was measured at the beginning of each 24-h exposure period. Temperature, salinity and $\mathrm{pH}$ were measured at the beginning and end of each 24-h exposure period.

\subsection{Cortisol after a 24-h exposure period}

Cortisol measurements ( 3 replicates of 7 larvae each) were made after a 24-h exposure period since cortisol levels generally peak during the first $24 \mathrm{~h}$ after an acute salinity challenge in Fundulus heteroclitus and other fish species (Marshall et al., 1999; Kajimura et al., 2004) and are 
expected to be back to normal levels after $96 \mathrm{~h}$. This transient rise in cortisol triggers the osmoregulatory responses necessary for maintenance of water content and optimal growth. Thus, it is expected that an abnormal cortisol response in the first hours after a salinity challenge could have delayed impact on osmotic control and growth (Liebert and Schreck, 2006).

At the end of the 24-h exposure period, $840 \mu \mathrm{L}$ of an anaesthetizing solution of clove oil: ethanol 1:10 was added directly to the jars to obtain a final concentration of $40 \mathrm{mg} / \mathrm{L}$ clove oil (Sigma, Oakville, ON, Canada, 98\% purity) in the exposure media. Clove oil was used since it was found to prevent the cortisol stress response associated with handling in fish (Small, 2003). After $3 \mathrm{~min}$ immersion in clove oil, larvae were frozen immediately in liquid nitrogen and stored to $-80^{\circ} \mathrm{C}$ until cortisol analysis. In order to minimize stress, length of these larvae was not measured.

Frozen larvae from each replicate were pooled in two groups of two larvae and one group of three larvae, then weighed to the nearest $0.1 \mathrm{mg}$. They were homogenized in ED1 buffer (R\&D Systems, Minneapolis, MN, USA) at a ratio of $150 \mu \mathrm{L} /$ larva with a polypropylene pellet pestle (Sigma-Aldrich, Oakville, ON, Canada). Steroid displacement reagent (R\&D Systems) was added to the homogenates in proportion 1:100 (v/v). Homogenates were centrifuged twice at $4^{\circ} \mathrm{C}$ (12 $500 \mathrm{~g}, 30 \mathrm{~min}$, and then $\left.10 \mathrm{~min}\right)$ and supernatants kept on ice. Cortisol concentrations were quantified using a commercially available enzyme-linked immunosorbent assay (ELISA) kit (R\&D Systems) in which cortisol present in samples competes with a fixed amount of alkaline phosphatase-labeled cortisol for sites on a mouse monoclonal antibody. This complex binds a goat anti-mouse polyclonal antibody coated onto the microplate. The ELISA plates were read at $405 \mathrm{~nm}$ using a Multiskan ${ }^{\circledR}$ Ascent (Titertek, Huntsville, AL, USA) and readings at $570 \mathrm{~nm}$ were subtracted to correct for optical imperfection in the plate. Samples were analyzed in 
duplicate. Average coefficient of variation (CV) among duplicates was $3.5 \pm 3.1 \%$. Cortisol contents in the homogenates were calculated and expressed on a per larva basis (larval cortisol content) or on a wet mass basis (larval cortisol concentration) for purpose of comparison with the literature.

The ELISA method was validated for measuring mummichog cortisol in whole larval homogenates by verifying that serial dilutions of these samples inhibited the binding of alkaline phosphatase-labeled cortisol in the same way as cortisol standards (R\&D Systems). The slopes of the relationship between percentage of binding $\left(\mathrm{B} / \mathrm{B}_{0}\right)$ and concentration of standard or dilution factor did not differ between cortisol standard and serial dilutions of larval homogenates $(P>0.05)$. Parallel slopes indicated no apparent interference of larval homogenate components on antibody/cortisol binding parameters.

\subsection{Larval condition and water content after a 96-h exposure period}

For determination of treatment effects on larval condition (length, condition factor, percentages of proteins, lipids and residual masses) and water content, a 96-h static test was conducted with daily renewal of the solutions. At the end of exposure, larvae were anaesthetized in carbonated water $\left(560 \mathrm{mg} / \mathrm{L} \mathrm{HCO}_{3}{ }^{-}, 1000 \mathrm{mg} / \mathrm{L}\right.$ mineral salts; Saint-Justin Co. Maskinonge, QC, Canada) instead of clove oil that could possibly interfere with lipid determination. Total body length was measured to the nearest $0.1 \mathrm{~mm}$ with a binocular microscope equipped with an ocular micrometer. To determine wet mass, larvae were blotted dry, weighed to the nearest $0.1 \mathrm{mg}$ on an analytical balance, then immediately frozen individually in liquid nitrogen and stored at $-80^{\circ} \mathrm{C}$. Larvae were lyophilized until constant mass was attained. Larvae were kept in a 
dessicator until dry mass was determined to the nearest $0.001 \mathrm{mg}$. Wet and dry masses were used to calculate percentages of water. Length and dry masses were used to calculate condition factor (length/ dry mass X 100) as recommended by Safran (1992) for juvenile fish. Lyophilized larvae were individually homogenized with a polypropylene pellet pestle in $150 \mu \mathrm{L}$ of sodium phosphate buffer $(0.2 \mathrm{M}, \mathrm{pH}=7.0)$. Two aliquotes $(75 \mu \mathrm{l}$ each) were used for protein and lipid analysis, respectively.

Lipids were extracted following the Bligh and Dyer method (Bligh and Dyer, 1959). Extractable lipids were measured using the sulpho-phospho-vanillin method described by Izard and Limberger (2003). Briefly, this method consists of oxidizing cellular lipids to small fragments after chemical digestion with hot concentrated sulfuric acid. After the addition of a solution of vanillin and phosphoric acid, a red complex is formed. Samples were analyzed in triplicates at $530 \mathrm{~nm}$ with a Multiskan ${ }^{\circledR}$ ascent spectrophometer. Lipid concentration in larval homogenates was determined using olive oil as a standard. Average CV among triplicates was $3.2 \pm 6.4 \%$. Lipids in larvae (\% dry mass) were calculated.

After centrifugation $\left(10000 \mathrm{~g}, 10 \mathrm{~min}\right.$ at $\left.4^{\circ} \mathrm{C}\right)$ supernatants were analysed for soluble protein content with Bradford reagent. Protein concentration in larval homogenates was determined using bovine serum albumin (BIO-RAD Laboratories, Hercules, CA, USA) as a standard. Samples were analyzed in triplicates at $595 \mathrm{~nm}$ using a Multiskan ${ }^{\circledR}$ ascent spectrophotometer. Average $\mathrm{CV}$ among triplicates was $6.6 \pm 5.0 \%$. Proteins in larvae (\% dry mass) were calculated. Residual mass [defined as dry body mass-(lipid+protein content)] was also calculated and expressed as percentage of dry mass (Ali et al., 2006).

\subsection{Chemical analysis}


Atrazine and desethylatrazine were analysed in the following exposure solutions: atrazine nominal concentration of $0 \mu \mathrm{g} / \mathrm{L}$ on day 0 for each test salinity; all atrazine nominal concentrations $(0,5,50$ and $500 \mu \mathrm{g} / \mathrm{L})$ at the beginning (t-0) and end (t-24) of each 24-h exposure period in salinity $15 \mathrm{PSU}$; high $(500 \mu \mathrm{g} / \mathrm{L})$ and low $(5 \mu \mathrm{g} / \mathrm{L})$ nominal concentrations at $\mathrm{t}-0$ and $\mathrm{t}-24$ on the last day at salinity 3 PSU and 35 PSU. These measurements were used to assess: potential contamination of the controls; variability associated to the technique of preparation of the solution and/or to the potential degradation of atrazine during 24-hr at salinity 15PSU; the effect of salinity on the potential degradation of atrazine during a 24-hr exposure period. A replicate was prepared specifically for chemical analyses at the beginning $(\mathrm{t}-0)$ of each 24-h exposure period. Chemical analyses at the end (t-24) of each 24-h exposure period of the 96-h assay were performed on pooled water samples of all 4 replicates. Various volumes of exposure solutions were collected, depending on the nominal atrazine concentration, and transferred into a clean glass bottle with $10 \mathrm{ng}$ of the labeled surrogate compound ${ }^{13} \mathrm{C}_{12} \mathrm{PCB}-101$ to assess the extraction efficiency. Extraction was performed 3 times with a volume of dichloromethane corresponding to approximately $25 \%$ of the collected solution. Combined extracts were then reduced to about $50 \mu \mathrm{L}$ and completed with $50 \mu \mathrm{L}$ of tris(4chlorophenyl)methane (TCPMe, $100 \mathrm{pg} / \mu \mathrm{L})$ as internal standard.

Analysis was conducted on a gas chromatograph (GC) equipped with a DB-5MS capillary column (30 m X 0.25 mm i.d. X $0.25 \mu \mathrm{m}$ film thickness, J\&W Scientific, Folson, CA, USA) coupled to a Varian Saturn 2000 ion trap mass spectrometer (MS) by a transfer line kept at $300^{\circ} \mathrm{C}$. The injector was operated in splitless mode. Helium was used as the carrier gas (flow rate, $1.0 \mathrm{~mL} / \mathrm{min}$ ). The ionization was performed by electron impact at $70 \mathrm{eV}$ and the ion trap 
was operated in MS-MS mode. GC-MS analysis was performed by using the following conditions: injector temperature $90^{\circ} \mathrm{C}-310^{\circ} \mathrm{C}\left(90^{\circ} \mathrm{C}\right.$ for $0.3 \mathrm{~min} ; 200^{\circ} \mathrm{C} / \mathrm{min}$ to $310^{\circ} \mathrm{C}$, held for $44 \mathrm{~min})$, oven temperature $90^{\circ} \mathrm{C}-300^{\circ} \mathrm{C}\left(90^{\circ} \mathrm{C}\right.$ for $1.2 \mathrm{~min} ; 30^{\circ} \mathrm{C} / \mathrm{min}$ to $150^{\circ} \mathrm{C} ; 1.5^{\circ} \mathrm{C} / \mathrm{min}$ to $190^{\circ} \mathrm{C}$, held for $1 \mathrm{~min} ; 8^{\circ} \mathrm{C} / \min$ to $260^{\circ} \mathrm{C} ; 30^{\circ} \mathrm{C} / \min$ to $300^{\circ} \mathrm{C}$, held for $3 \mathrm{~min}$ ) and ion trap temperature $250^{\circ} \mathrm{C}$.

Atrazine and desethylatrazine concentrations were calculated on the basis of their response relative to the one of ${ }^{13} \mathrm{C}_{12}$ PCB-101 in the same sample. Relative response factor was determined on the basis of a four point calibration curve for atrazine and desethylatrazine, while ${ }^{13} \mathrm{C}_{12}$ PCB-101 and TCPMe were kept at constant concentration $(100 \mathrm{pg} / \mu \mathrm{L})$. Atrazine and desethylatrazine concentrations were corrected on the basis of the recovery of the surrogate compound. Limit of quantification was $0.003 \mathrm{ng} / \mathrm{L}$ for both atrazine and desethylatrazine. Analytical precision was $6 \%$.

\subsection{Statistical analysis}

The effects of salinity and of exposure to different concentrations of atrazine on cortisol (24-h exposure) or on body length, condition factors, percentages of proteins, lipids, residual mass and water (96-h exposure) were assessed by two-way ANOVA with interaction conducted on the mean values of the replicates ( $\mathrm{N}=4$ jars per treatment). Following significant ANOVA, a Tukey's multiple comparison test was applied. Data met with the requirements for normality (Shapiro-Wilk’s test) and homogeneity of variance (Levene's test).

Graphical examination of the linear relationship between water mass and dry mass revealed the presence of severely affected larvae with either very low or very high water content. 
Larvae with water percentages $\geq 2$ standard deviations from the mean of control larvae (salinity 15 PSU, atrazine $0 \mu \mathrm{g} / \mathrm{L}$ ) were considered to be severely affected ( $\leq 81 \%$, dehydrated or $\geq 85 \%$, hyperhydrated). The prevalence of dehydrated or hyperhydrated larvae were compared between each treatment and control using a two-tailed Fisher's exact test.

The severity of dehydratation of each dehydrated larvae was graded from 2 to 6 based on the deviation of its percentage of water from the mean percentage in control larvae (number of standard deviations from the mean). The severity of dehydratation was compared among treatments with significantly enhanced percentages of severely affected larvae using a KruskallWallis test followed by a Tukey's multiple comparison test.

The prevalence of larvae with condition factor $\geq 2$ standard deviations from control mean was also compared among treatments using a two-tailed Fisher's exact test. Condition factors of dehydrated and hyperhydrated larvae were compared to condition factors of larvae with normal water content by one-way ANOVA within treatments. Statistical analyses were performed with SAS software (SAS Institute, Cary, NC, USA). All differences were tested at a probability $(\alpha)$ of 0.05 .

\section{Results}

\subsection{Water quality parameters and chemical analysis}

Characteristics of the test water at $\mathrm{t}-0$ for the three different salinities were: salinity $=3.1 \pm 0.1 \mathrm{PSU}, \quad \mathrm{pH}=8.0 \pm 0.2$ and temperature $=21.6 \pm 0.6^{\circ} \mathrm{C} ; \quad$ salinity $=15.1 \pm 0.1 \mathrm{PSU}$ $\mathrm{pH}=7.8 \pm 0.1 \quad$ and $\quad$ temperature $=21.6 \pm 0.5^{\circ} \mathrm{C} ; \quad$ salinity $=35.1 \pm 0.1 \mathrm{PSU}, \quad \mathrm{pH}=7.9 \pm 0.1 \quad$ and 
temperature $=21.6 \pm 0.5^{\circ} \mathrm{C}$ (mean \pm standard deviation). At $\mathrm{t}-24$, there were: salinity $=3.1 \pm 0.1 \mathrm{PSU}$, $\mathrm{pH}=7.7 \pm 0.2 \quad$ and $\quad$ temperature $=20.6 \pm 0.2^{\circ} \mathrm{C} ; \quad$ salinity $=15.1 \pm 0.1 \mathrm{PSU}, \quad \mathrm{pH}=7.6 \pm 0.2 \quad$ and temperature $=20.6 \pm 0.2^{\circ} \mathrm{C} ; \quad$ salinity $=35.0 \pm 0.2 \mathrm{PSU}, \mathrm{pH}=7.8 \pm 0.1$ and temperature $=20.6 \pm 0.1^{\circ} \mathrm{C}$. Dissolved oxygen remained $>95 \%$ of saturation throughout the experiment. Water quality conditions $\left(\mathrm{pH}\right.$, temperature and $\left.\mathrm{O}_{2}\right)$ did not differ among treatments.

Measured atrazine concentrations at t-0 (Table 1) were within $85-105 \%$ of the nominal concentrations. The single measurement of atrazine for each treatment at salinities 3 and 35 PSU was within the range observed for the corresponding treatment at salinity 15 PSU. Larvae were exposed to nearly constant atrazine concentrations over the bioassay period. Variations of atrazine concentration within each $24-\mathrm{h}$ period were of the same amplitude as the day to day variation at $\mathrm{t}-0$. In blanks at the three salinities, atrazine was occasionally detected in trace amounts $(<0.02 \mu \mathrm{g} / \mathrm{L})$. Desethylatrazine was not detected, except in trace amounts $(0.004$ and $0.013 \mu \mathrm{g} / \mathrm{L})$ at the highest atrazine concentration at salinity 3 and 35 PSU, respectively, on the first day of exposure.

\subsection{Cortisol}

No larvae died during the first $24-\mathrm{h}$ exposure period. Salinity or atrazine concentration did not significantly affect cortisol content in larvae (Table 2). Cortisol content in whole larvae presented a high degree of variability within treatment. Coefficient of variation in control (salinity $15 \mathrm{PSU}$, and $0 \mu \mathrm{g} / \mathrm{L}$ atrazine) was $13 \%$. The highest coefficient of variation (40\%) was observed in salinity $15 \mathrm{PSU}, 500 \mu \mathrm{g} / \mathrm{L}$ atrazine. The variability observed could not be reduced by expressing cortisol as concentration (\% wet mass) rather than per whole larvae and no significant 
effect of treatments on cortisol concentrations was detected (ANOVA $\mathrm{p}>0.05$ ). Cortisol concentration in control was $106 \pm 14 \mathrm{ng} / \mathrm{g}$ (wet mass).

\subsection{Larval condition}

No larvae died during the 96-h exposure period. Salinity or atrazine had no effect on body length, percentages of proteins, lipids or residual masses (Table 3). Larval dry masses ranged from 0.274 to $0.460 \mathrm{mg}$. The prevalence of larvae with a condition factor $\geq 2$ standard deviations from control mean did not differ significantly among treatments (Fisher's exact test, $P>0.05$ ). No interaction was detected between atrazine and salinity effects on condition factor (Table 3). Salinity affected condition factor of larvae, with lower condition factor at salinity 3 PSU and 35 PSU than at salinity $15 \mathrm{PSU}$. The highest atrazine concentration, $500 \mu \mathrm{g} / \mathrm{L}$, elicited a significant decrease in condition factor. Condition factors of dehydrated ( $\leq 81 \%$ water) or hyperhydrated ( $\geq 85 \%$ water) larvae did not differ from condition factors of larvae with normal percentages of water within treatments (ANOVA, $\mathrm{p}>0.05$ ).

\subsection{Water content}

No interaction was detected between atrazine and salinity effects on the percentages of water. Mean percentages of water in whole-larvae were affected by salinity; a higher percentage of water was found at salinity 3 PSU than at salinity 15 and 35 PSU. No significant effect of atrazine concentration on mean percentages of water was detected by ANOVA (Table 3). 
In the absence of atrazine, salinity had no effect on the prevalence of dehydrated or hyperhydrated larvae (Figure 1). At atrazine concentrations $\geq 5 \mu \mathrm{g} / \mathrm{L}$, the prevalence of dehydrated larvae was significantly increased at salinity 15 and 35 PSU (prevalence of dehydrated larvae ranging from 28 to $42 \%$ at $\geq 5 \mu \mathrm{g} / \mathrm{L}$ compared to $7 \%$ in controls) (Fisher's exact test, $\mathrm{p} \leq 0.05$ ). At salinity $35 \mathrm{PSU}$, the dehydratation was significantly more severe at the highest $(500 \mu \mathrm{g} / \mathrm{L})$ compared to the lowest $(5 \mu \mathrm{g} / \mathrm{L})$ concentration of atrazine, with water percentages as high as 6 standard deviation from control mean at $500 \mu \mathrm{g} / \mathrm{L}$ (Kruskal WallisW, p $\leq 0.05$; Figure 2). At salinity 15 PSU, the severity of dehydration did not differ significantly among atrazine concentrations. The prevalence of hyperhydrated larvae was significantly increased at salinity $3 \mathrm{PSU}, 5 \mu \mathrm{g} / \mathrm{L}$ atrazine (prevalence of hyperhydrated larvae of $23 \%$ compared to $0 \%$ in controls; Fisher's exact test, $\mathrm{p} \leq 0.05$ ) whereas it was not affected at higher concentrations of atrazine.

\section{Discussion}

This study shows that short-term exposure to environmentally realistic concentrations of atrazine affects osmotic control in mummichog larvae. Without atrazine, no change in the prevalence of severely hyperhydrated or dehydrated larvae was observed in response to changes in salinity. Atrazine affected the prevalence of hyperhydrated and dehydrated larvae without affecting the mean percentages of water, suggesting that some individual larvae were more vulnerable to atrazine toxicity. At higher salinities (15 and 35 PSU) than isosmotic salinity for mummichog (10-12 PSU), larvae faced water loss by passive diffusion (Varsamos et al., 2005). In absence of atrazine, larvae controlled their water content at these salinities. Atrazine induced an osmoregulatory imbalance in some larvae with an increase in the prevalence of dehydrated 
larvae at $5-500 \mu \mathrm{g} / \mathrm{L}$. The most severe effects were observed in larvae exposed to $500 \mu \mathrm{g} / \mathrm{L}$ at 35 PSU. At salinity 3 PSU, larvae faced water invasion by passive diffusion. Prevalence of hyperhydrated larvae increased at $5 \mu \mathrm{g} / \mathrm{L}$ compared to control indicating osmoregulatory disturbances induced by atrazine. In Atlantic salmon smolts, similar atrazine concentrations $(\geq 6.5 \mu \mathrm{g} / \mathrm{L})$ affected osmoregulation and gill $\mathrm{Na}^{+} \mathrm{K}^{+}$ATPase activity which is directly related to the size and number of gill chloride cells (Waring and Moore, 2004). Newly-hatched mummichog larvae have functional chloride cells on their gill filaments that could be affected by atrazine exposure (Kanekoh and Katoh, 2004). Water content was not altered at higher atrazine concentrations. At these concentrations $(50,500 \mu \mathrm{g} / \mathrm{L})$, water content may be negatively affected by a loss of condition counteracting the positive effect of osmotic imbalance (Couture et al., 1998; Bureau et al., 2000). Further studies with larger sample size and thus higher precision of the estimate of the prevalence of abnormal larvae are required to better define the concentrationresponse relationship and to determine the no-observed-adverse-effect-concentration.

Loss of osmotic control in fish larvae observed in this study may influence larval buoyancy that is a critical determinant of growth and survival (Sclafani et al., 1997; Moustakas et al., 2004). To fully evaluate the ecological significance of our findings, the buoyancy of hyperhydrated and dehydrated mummichog larvae should be measured and its impact on the interactions of the larvae with preys or predators should be assessed.

After a 96-h exposure period, salinity had no effect on the reduction in body condition caused by atrazine. Atrazine reduced condition factor of larvae only at the highest concentration tested, $500 \mu \mathrm{g} / \mathrm{L}$. The lowest atrazine concentration reported to affect fish condition (expressed as mean wet mass and mean length) was $120 \mu \mathrm{g} / \mathrm{L}$ for newly hatched freshwater brook trout (Salvelinus fontinalis) after a 306-day exposure period (Macek et al., 1976). Atrazine reduced 
growth rate after a 9-day exposure period in red drum larvae at $80 \mu \mathrm{g} / \mathrm{L}$ at $27 \mathrm{PSU}$ but this reduction was not significant after a 96-h exposure period (Alvarez and Fuiman, 2005). A longer period of observation of the mummichog larvae, following a pulse exposure to atrazine, may be necessary to reveal significant impacts on growth or condition.

The reduction in condition of larvae in response to salinity and/or atrazine could not be attributed to enhance use of body reserves since percentages of proteins, lipids or residual masses were not affected. Prevailing growth mechanisms in larvae are increased in length and axial expansion of muscles and developing organs (Couture et al., 1998). Body length was not affected by the treatments. Reduction in condition probably originated from a reduction in axial growth with a decrease in tissues synthesised, since body composition was not affected. Atrazineexposed red drum larvae were hyperactive at concentration $\geq 40 \mu \mathrm{g} / \mathrm{L}$ (Alvarez and Fuiman, 2005). Thus, hyperactivity could have contributed to reduction in larval condition observed in our study but changes in behaviour were not assessed.

Our results confirm that the near isosmotic salinity of $15 \mathrm{PSU}$ was optimal for mummichog larvae among the three salinities tested. Larvae had slightly higher percentages of water at hyposmotic salinity compared to near isosmotic or hyperosmotic salinities, regardless of atrazine concentration. This indicates incapacity of the larvae to entirely counteract passive water invasion at this low salinity. This result is consistent with the fact that mummichog are better adapted to hyperosmotic than to hyposmotic environments (Kaneko and Katoh, 2004). It also affected condition of larvae, with lower condition factor at salinity 3 and 35 PSU than at the near isosmotic salinity of 15 PSU. This result is in agreement with the observation that fry body length was highest at the near isosmotic salinity of 20 PSU in mummichog incubated in salinities ranging from 0.5 to 60 PSU from fertilisation to fry stage (Tay \& Garside, 1978). 
Salinity did not affect dissolved concentration or degradation rate of atrazine. Indeed, measured atrazine concentrations for each nominal concentration were similar among salinities and were stable over the 24-h exposure periods. However, salinity may have affected the absorption of atrazine in the larvae and studies with radiolabelled atrazine could be conducted to test this hypothesis (Blanchard and Grosell, 2005).

This is the first study that reports cortisol content in mummichog larvae $(217 \pm 29 \mathrm{pg} / \mathrm{larva}$ in controls, salinity $15 \mathrm{PSU}, 0 \mu \mathrm{g} / \mathrm{L}$ atrazine). Similar cortisol content ( $140 \mathrm{pg} / \mathrm{larva})$ has been reported in 1 day post-hatch (dph) silver sea bream (Sparus sarba) larvae (Deane and Woo, 2003). Length and dry masses of $1 \mathrm{dph}$ silver sea bream larvae are in the same range as those of mummichog larvae (Deane et al., 2003). Lower cortisol concentrations have been reported in the larvae of other fish species such as rainbow trout (Onchorynchus mykiss) $(0.3 \mathrm{ng} / \mathrm{g}$ wet mass 1 dph larvae) or red drum (Sciaenops ocellatus) (undetectable in 0-1 dph larvae) (Barry et al., 1995; Pérez-Domingez and Holt, 2006).

Neither atrazine nor salinity had detectable effects on cortisol content. Considering the high variability of cortisol content and the sample size $(n=3)$, the experimental design provided an $80 \%$ power to detect a $27 \%$ change in cortisol. This power was sufficient to detect a typical cortisol response to an acute salinity challenge with $>500 \%$ elevation in cortisol concentrations (Marshall et al., 1999; Pérez-Dominguez and Holt, 2006). The time course of salinity adaptation has not been described in larval mummichog. It is possible that a cortisol response has occurred shortly after transfer of the larvae in the exposure jars and was no longer detectable after $24 \mathrm{~h}$. In adult mummichog, cortisol levels were elevated $24 \mathrm{~h}$ after transfer from freshwater to seawater (Marshall et al., 1999). It is also possible that one day after hatching, mummichog larvae were not able to produce cortisol or that their response was masked by cortisol from maternal origin (Stouthart et al., 1998; Pérez-Dominguez and Holt, 2006). Measurement of cortisol in blood 
would have provided a better indication of the response of the larvae than whole-body cortisol but it was not technically possible given the small-size of the mummichog larvae.

\section{Conclusion}

Environmentally relevant concentrations $(5 \mu \mathrm{g} / \mathrm{L})$ of atrazine affected the capacity of mummichog larvae to osmoregulate with higher prevalence of dehydrated larvae (at salinity 15 and 35 PSU) or hyperhydrated larvae (at salinity 3 PSU). Severity of dehydration increased with atrazine concentration at salinity 35 PSU. After a 96-h exposure period significant reduction in condition was only observed at $500 \mu \mathrm{g} / \mathrm{L}$, a concentration rarely encountered in the environment. Further work is needed to determine the no-observed-adverse-effect-concentration (NOEC) and to assess the effect of observed changes in water content on larval buoyancy, growth and survival of mummichog larvae. The experimental model developed in this study could be used to evaluate the interaction between salinity and other toxic compounds encountered in estuarine and coastal waters.

\section{Acknowledgements}

We thank B. Légaré, M.-C. Marquis and H. Talbot for their technical assistance with the bioassays and the fish cultures. We also thank B. Légaré and P. Rioux for their assistance with biochemical measurements and S. Trottier for chemical analyses of test water samples. This project was funded by the Environmental Strategic Science Research Fund and the Pesticide Research Program of the Department of Fisheries and Oceans. 


\section{References}

Alazemi, B.M., Lewis, J.W., Andrews, E.B. (1996). Gill damage in the freshwater fish Gnathonemus petersii (family: Mormyridae) exposed to selected pollutants: An ultrastructural study. Environmental Technology, 17, 225-238.

Ali, M., Iqbal F., Salam A., Athar, M. (2006). Comparative study of body composition of four fish species in relation to pond depth. International Journal of Environmental Sciencee and Technology, 2, 359-364.

Alvarez, M.d.C., Fuiman, L.A. (2005). Environmental levels of atrazine and its degradation products impair survival skills and growth of red drum larvae. Aquatic Toxicology, $74,229-241$.

ASTM [American Society for Testing and Materials] (2004). Standard guide for conducting early life-stage toxicity tests with fishes. Method E1241-98. Annual Book of ASTM standards. ASTM International Philadelphia, PA, USA, 11.05, 941-967.

Barry, T.P., Malison, J.A., Held, J.A., Parrish, J.J., 1995. Ontogeny of the cortisol stress response in larval rainbow trout. General and Comparative Endocrinology, 97, 57-65.

Benguira, S., Leblond V.S., Webert, J.P., Hontela, A. (2002). Loss of capacity to elevate plasma cortisol in rainbow trout (Oncorhynchus mykiss) treated with a single injection of o,p'dichlorodiphenyldichloroethane. Environmental Toxicology and Chemistry, 21, 17531756.

Bisson, M., Hontela, A. (2002). Cytotoxic and endocrine-disrupting potential of atrazine, diazinon, endosulfan, and mancozeb in adrenocortical steroidogenic cells of rainbow trout exposed in vitro. Toxicology and Applied Pharmacology, 180, 110-117. 
Blanchard, J., Grosell, M. (2005). Effects of salinity on copper accumulation in the common killifish (Fundulus heteroclitus). Environmental Toxicology and Chemistry, 24, 14031413.

Bligh, E.G., Dyer, W.J. (1959). A rapid method of total lipid extraction and purification. Canadian Journal of Biochemistry and Physiology, 37, 911-917.

Boeuf, G., Payan, P. (2001). How should salinity influence fish growth? Review. Comparative Biochemistry and Physiology C : Pharmacology Toxicology and Endocrinology, 130, 411-423.

Boyd, J.F., Simmonds, R.C. (1974). Continuous laboratory production of fertile Fundulus heteroclitus (Walbaum) eggs lacking chorionic fibrils. Journal of Fish Biology, 6, 389394.

Bureau, B.P., Azevedo, P.A., Tapia-Salazar, M., Cuzon, G. (2000). Pattern and cost of growth and nutrient deposition in fish and shrimp: Potential implications and applications. In: Cruz -Suárez, L.E., Ricque-Marie, D., Tapia-Salazar, M., Olvera-Novoa, M.A. y CiveraCerecedo, R. (Eds.), Avances en Nutrición Acuícola V. Memorias del V Simposium Internacional de Nutrición Acuícola. 19-22 Noviembre, 2000. Mérida, Yucatán, Mexico.

Couillard, C.M. (2002). A microscale test to measure petroleum oil toxicity to mummichog embryos. Environmental Toxicology , 17, 195-202.

Couillard, C.M., Nellis, P. (1999). Organochlorine contaminants in mummichog (Fundulus heteroclitus) living downstream from a bleached kraft pulp mill in the Miramichi Estuary, New Brunswick, Canada. Environmental Toxicology and Chemistry, 18, 2545-2556. 
Couture, P., Dutil, J.D., Guderley, H. (1998). Biochemical correlates of growth and condition in juvenile Atlantic cod (Gadus morhua) from Newfoundland. Canadian Journal of Fisheries and Aquatic Sciences, 55, 1591-1598.

Deane, E.E., Kelly, S.P., Collins, P.M., Woo, N.Y.S. (2003). Larval development of Silver sea bream (Sparus sarba): ontogeny of RNA-DNA ratio, GH, IGF-I, and $\mathrm{Na}^{+}-\mathrm{K}^{+}$-ATPase. Marine Biotechnology, 5, 79 - 91.

Deane, E.E., Woo, N.Y.S. (2003). Ontogeny of thyroid hormones, cortisol, hsp70 and hsp90 during silver sea bream larval development. Life Sciences, 72, 805-818.

De Lorenzo, M.E., Scott, G.I., Ross, P.E. (2001). Toxicity of pesticides to aquatic microorganisms: a review. Environmental Toxicology and Chemistry, 20, 84-98.

Griffith, R.W. (1974). Environment and salinity tolerance in the genus Fundulus. Copeia, 2, 319331.

Gravel A., Campbell P.G.C., Hontela, A. (2005). Disruption of the hypothalamo-pituitaryinterrenal axis in $1+$ yellow perch (Perca flavescens) chronically exposed to metals in the environment. Canadian Journal of Fisheries and Aquatic Sciences, 62, 982-990.

Hall, L.W. Jr., Anderson, R.D. (1995). The influence of salinity on the toxicity of various classes of chemicals to aquatic biota. Critical Reviews in Toxicology, 25, 281-346.

Hall, L.W. Jr., Ziegenfuss, M.C., Anderson, R.D., Spittler, T.D., Leichtweis, H.C. (1994). Influence of salinity on the chronic toxicity to a Chesapeake Bay copepod (Eurytemora affinis) and fish (Cyprinodon variegates). Estuaries, 17, 181-186.

Hanke, W., Gluth, G., Bubel, H., Muller, R. (1983). Physiological changes in carps induced by pollution. Ecotoxicology and Environmental Safety, 7, 229-241. 
Houde, E.D. (1987). Fish early life dynamics and recruitment variability. American Fisheries Society Symposium, 2, 17-29.

Houde, E.D. (1989). Subtleties and episodes in the early life of fishes. Journal of Fish Biology, supplément A, 29-38.

Izard, J., Limberger, R.J. (2003). Rapid screening method for quantitation of bacterial cell lipids from whole cells. Journal of Microbiological Methods, 55, 411-418.

Joseph, E.B., Saksena, V.P. (1966). Determination of salinity tolerances in mummichog (Fundulus heteroclitus) larvae obtained from hormone-induced spawning. Chesapeake Sciences, 7, 193-197.

Kajimura, S., Hirano, T., Moriyama, S., Vakkuri, O., Leppäluoto, J., Grau, G. (2004). Changes in plasma concentrations of immunoreactive ouabain in the tilapia in response to changing salinity: is ouabain a hormone in fish? General and Comparative Endocrinology, 135, 9099.

Kaneko, T., Katoh, F. (2004). Functional morphology of chloride cells in killifish Fundulus heteroclitus, a euryhaline teleost with seawater preference. Fisheries Sciences, 70, 723733.

Kennedy, C.J., Farrell A.P. (2005). Ion homeostasis and interregnal stress responses in juvenile Pacific herring, Clupea pallasi, exposed to the water-soluble fraction of crude oil. Journal of Experimental Marine Biology and Ecology, 323, 43-56.

Liebert, A.M., Schreck, C.B. (2006). Effects of acute stress on osmoregulation, feed intake, IGF1 and cortisol in yearling steelhead trout (Oncorhynchus mykiss) during seawater adaptation. General and Comparative Endocrinology, 148, 195-202. 
Macek, K.J., Burton, K.S., Sauter, S., Gnilka, S., Dean, J.W. (1976). Chronic toxicity of atrazine to selected aquatic invertebrates and fishes. EPA-600/3-76-047. National Technical Information Service, Springfield, VA, USA.

Marshall, W.S., Emberley, T.R., Singer, T.D., Bryson, S.E., McCormick, S.D. (1999). Time course of salinity adaptation in a strongly euryhaline estuarine teleost, Fundulus heteroclitus: a multivariable approach. Journal of Experimental Biology, 202, 1535-1544.

Moore, A., Lower, N. (2001). The impact of two pesticides on olfactory-mediated endocrine function in mature male Atlantic salmon (Salmo salar L.) parr. Comparative Biochemistry and Physiology B, 129, 269-276.

Moustakas C.Th., Watanabe, W.O., Copeland, K.A. (2004). Combined effects of photoperiod and salinity on growth, survival, and osmoregulatory ability of larval southern flounder Paralichthys lethostigma. Aquaculture, 229, 159-179.

Pérez-Domínguez, R., Holt, G.J. (2006). Interrenal and thyroid development in red drum (Sciaenops ocellatus): effects of nursery environment on larval growth and cortisol concentration during settlement. General and Comparative Endocrinology, 146, 108-118.

Safran P. (1992). Theoretical analysis of the weight-length relationship in fish juveniles. Marine Biology, 112, 545-551.

Schwaiger, J., Veeser, A., Ewringmann, T., Negele, R.D. (1991). Darstellung subletaler wirkung von umweltchemikalien auf regenbogenforellen (Oncorhynchus mykiss). Muenchener Beitraege zur Abwasser- Fischerei- und Flussbiologie, 45, 130-144.

Sclafani, M., Stirling, G., Leggett, W.C. (1997). Osmoregulation, nutritional effects and buoyancy of marine larval fish: a bioassay for assessing density changes during the earliest life-history stages. Marine Biology, 129, 1-9. 
Small, B.C. (2003). Anesthetic efficacy of metomidate and comparison of plasma cortisol responses to tricaine methanesulfonate, quinaldine and clove oil anesthetized channel catfish Ictalurus punctatus. Aquaculture, 218, 177-185.

Stouthart A.J., Lucassen E.C., van Strien F.J., Balm P.H., Lock R.A., Wendelaar Bonga S.E. (1998). Stress responsiveness of the pituitary-interrenal axis during early life stages of common carp (Cyprinus carpio). Journal of Endocrinology, 157, 127-137.

Tay, K.L., Garside, E.T. (1978). Compensatory embryogenic responses in osmoregulative structures of mummichog Fundulus heteroclitus L. incubated at constant temperature and various levels of salinity. Canadian Journal of Zoology, 56, 613-623.

USEPA [U.S. Environmental Protection Agency] (2002). Reregistration eligibility science chapter for atrazine environmental fate and effects chapter. Washington, DC, USA. Available online at http://www.epa.gov/oppsrrd1/reregistration/atrazine/efed_redchap_22apr02.pdf.

Varsamos, S., Nebel, C., Charmantier, G. (2005). Ontogeny of osmoregulation in postembryonic fish: A review. Comparative Biochemistry and Physiology A, 141, 401-429.

Waring, C.P., Moore, A. (2004). The effect of atrazine on Atlantic salmon (Salmo salar) smolts in fresh water and after sea water transfer. Aquatic Toxicology, 66, 93-104.

Weis, J.S., Weis, P. (1987). Pollutants as developmental toxicants in aquatic organisms. Environmental Health Perspectives, 71, 77-85.

Zhou, T., Scali, R., Weis, S. (2001). Effects of methylmercury on ontogeny of prey capture ability and growth in three populations of larval Fundulus heteroclitus. Archives of Environmental Contamination and Toxicology, 41, 47-54. 


\section{Table 1.}

Nominal and measured atrazine concentrations in exposure solutions at the beginning $(\mathrm{t}=0)$ and end $(t=24)$ of 24-h exposure periods

\begin{tabular}{|c|c|c|c|}
\hline \multirow{2}{*}{$\begin{array}{l}\text { Salinity } \\
\text { (PSU) }\end{array}$} & \multirow{2}{*}{$\begin{array}{l}\text { Nominal concentrations } \\
\qquad(\mu \mathrm{g} / \mathrm{L})\end{array}$} & \multicolumn{2}{|c|}{ Measured concentrations $(\mu \mathrm{g} / \mathrm{L})$} \\
\hline & & $\mathrm{t}=0$ & $t=24$ \\
\hline \multirow[t]{3}{*}{3} & 0 & $<0.003$ & - \\
\hline & 5 & 4.50 & 5.49 \\
\hline & 500 & 492 & 491 \\
\hline \multirow[t]{4}{*}{15} & 0 & $0.004(<0.003-0.005)$ & $<0.003(<0.003)$ \\
\hline & 5 & $4.67(4.38-5.12)$ & $4.25(2.90-4.81)$ \\
\hline & 50 & $45.2(43.0-47.7)$ & $47.2(45.1-50.1)$ \\
\hline & 500 & $490(456-579)$ & $456(368-524)$ \\
\hline \multirow[t]{3}{*}{35} & 0 & 0.018 & - \\
\hline & 5 & 4.74 & 3.90 \\
\hline & 500 & 476 & 447 \\
\hline \multicolumn{4}{|c|}{ Values for salinity 15 PSU represent mean (range) of concentrations measured $(n=4)$; for oth } \\
\hline
\end{tabular}


Table 2 .

Effects of salinity and atrazine on cortisol content in mummichog larvae after a $24-\mathrm{h}$ exposure period

\begin{tabular}{|c|c|c|}
\hline Salinity (PSU) & Atrazine $(\mu \mathrm{g} / \mathrm{L})$ & Cortisol content (pg/larvae) \\
\hline \multirow[t]{4}{*}{3} & 0 & $164(43)$ \\
\hline & 5 & $147(35)$ \\
\hline & 50 & $154(19)$ \\
\hline & 500 & $221(42)$ \\
\hline \multirow[t]{4}{*}{15} & 0 & $217(29)$ \\
\hline & 5 & $190(21)$ \\
\hline & 50 & $187(30)$ \\
\hline & 500 & $174(70)$ \\
\hline \multirow[t]{4}{*}{35} & 0 & $177(41)$ \\
\hline & & $160(58)$ \\
\hline & 50 & $136(45)$ \\
\hline & 500 & $187(6)$ \\
\hline Salinity*atrazine & & $P=0.41$ \\
\hline Salinity effect & & $P=0.25$ \\
\hline Atrazine effect & & $P=0.23$ \\
\hline
\end{tabular}

Nominal concentrations of atrazine. Values are expressed as means $( \pm$ SE). Sample size was 3 pools of 2-3 whole larvae. No significant effect of salinity or atrazine and no significant interaction between treatments (two-ways ANOVA with interaction, $P>0.05$ ). 
Table 3 .

Effects of salinity and atrazine on body length, condition factor, percentages of water, proteins, lipids or residual mass of mummichog larvae after a 96-h exposure period

\begin{tabular}{|c|c|c|c|c|c|c|c|}
\hline $\begin{array}{l}\text { Salinity } \\
\text { (PSU) }\end{array}$ & $\begin{array}{l}\text { Atrazine } \\
(\mu \mathrm{g} / \mathrm{L})\end{array}$ & $\begin{array}{l}\text { Length } \\
(\mathrm{mm})\end{array}$ & $\begin{array}{l}\text { Condition factor } \\
\qquad(\mathrm{g} / \mathrm{cm})\end{array}$ & $\begin{array}{c}\text { Proteins } \\
\text { (\% dry mass) }\end{array}$ & $\begin{array}{c}\text { Lipids } \\
\text { (\% dry mass) }\end{array}$ & $\begin{array}{l}\text { Residual mass } \\
\text { (\% dry mass) }\end{array}$ & $\begin{array}{c}\text { Water } \\
\text { (\% wet mass) }\end{array}$ \\
\hline \multirow[t]{4}{*}{3} & 0 & $7.00(0.05)$ & $5.12(0.04)$ & $29.8(0.7)$ & $7.2(0.8)$ & $63.6(1.3)$ & $82.6(0.9)$ \\
\hline & 5 & $6.99(0.05)$ & $5.08(0.12)$ & $30.3(1.3)$ & $7.1(0.7)$ & $62.7(1.9)$ & $83.4(0.5)$ \\
\hline & 50 & $7.01(0.06)$ & $5.03(0.12)$ & $30.6(0.9)$ & $6.8(0.8)$ & $62.4(1.8)$ & $82.5(0.9)$ \\
\hline & 500 & $6.94(0.03)$ & $4.95(0.12)$ & $30.8(1.5)$ & $6.5(0.9)$ & $62.5(1.6)$ & $83.0(0.5)$ \\
\hline \multirow[t]{4}{*}{15} & 0 & $6.99(0.06)$ & $5.17(0.08)$ & $29.8(1.4)$ & $6.9(0.3)$ & $63.4(1.3)$ & $82.7(0.8)$ \\
\hline & 5 & $7.00(0.06)$ & $5.21(0.13)$ & $31.1(0.8)$ & $7.3(0.1)$ & $61.5(0.9)$ & $81.8(0.3)$ \\
\hline & 50 & $7.06(0.05)$ & $5.27(0.10)$ & $30.5(1.0)$ & $7.1(0.6)$ & $62.4(0.9)$ & $81.6(0.3)$ \\
\hline & 500 & $6.98(0.10)$ & $5.05(0.11)$ & $29.6(2.0)$ & $7.3(0.7)$ & $63.2(2.3)$ & $81.8(0.4)$ \\
\hline \multirow[t]{4}{*}{35} & 0 & $6.95(0.05)$ & $5.16(0.11)$ & $29.6(1.3)$ & $7.2(0.4)$ & $63.4(1.5)$ & $81.9(0.7)$ \\
\hline & 5 & $6.92(0.10)$ & $5.10(0.09)$ & $29.2(0.9)$ & $6.2(0.6)$ & $65.1(0.9)$ & $82.0(0.5)$ \\
\hline & 50 & $7.04(0.07)$ & $5.13(0.05)$ & $30.1(2.6)$ & $6.8(0.3)$ & $63.1(2.5)$ & $81.9(0.9)$ \\
\hline & 500 & $7.02(0.05)$ & $5.01(0.11)$ & $29.3(1.4)$ & $6.6(0.8)$ & $64.2(1.9)$ & $81.5(0.6)$ \\
\hline \multicolumn{2}{|c|}{ Salinity*atrazine } & $P=0.36$ & $P=0.68$ & $P=0.75$ & $P=0.29$ & $P=0.41$ & $P=0.36$ \\
\hline \multicolumn{2}{|c|}{ Salinity effect } & $P=0.50$ & $P=0.0033$ & $P=0.24$ & $P=0.15$ & $P=0.058$ & $P<0.0001$ \\
\hline & & & $3 b$ 15a 35b & & & & 3a 15b 35b \\
\hline \multirow{2}{*}{\multicolumn{2}{|c|}{ Atrazine effect }} & $P=0.08$ & $P=0.0025$ & $P=0.63$ & $P=0.61$ & $P=0.63$ & $P=0.24$ \\
\hline & & & 0a 5a 50a 500b & & & & \\
\hline
\end{tabular}

Nominal concentrations of atrazine. Condition factor: (dry mass/length*100). Values are expressed as means $( \pm \mathrm{SE})$. Sample size was 4 replicates of 10 larvae. Different letters indicate statistically different values (two-ways ANOVA with interaction, $P<0.05$ ). 


\section{Figure caption}

Fig. 1. Effect of salinity and atrazine on the prevalence of A) abnormally dehydrated larvae ( $\leq 81 \%$ water) and B) abnormally hyperhydrated larvae ( $\geq 85 \%$ water). Values are presented as percentages of affected larvae (bars) per treatment with $95 \%$ binomial proportion confidence intervals (vertical lines). Asterisks indicate statistical difference from control (salinity 15 PSU and $0 \mu \mathrm{g} / \mathrm{L}$ atrazine) using a two-tailed Fisher's exact test $(P<0.05)$.

Fig. 2. Severity of dehydratation in dehydrated larvae in treatments where the prevalence of severely affected larvae differed from control. The severity of dehydratation was graded from 2 to 6 based on the deviation of its percentage of water from the mean percentage of water in control larvae (number of standard deviations from the control's mean). Relative percentages of dehydrated larvae with different grade of dehydration are presented for each treatment. Different letters indicates statistically different distributions of severity of dehydration among treatments (Kruskal-Wallis, $\mathrm{p}<0.05$ ). 
Fig. 1
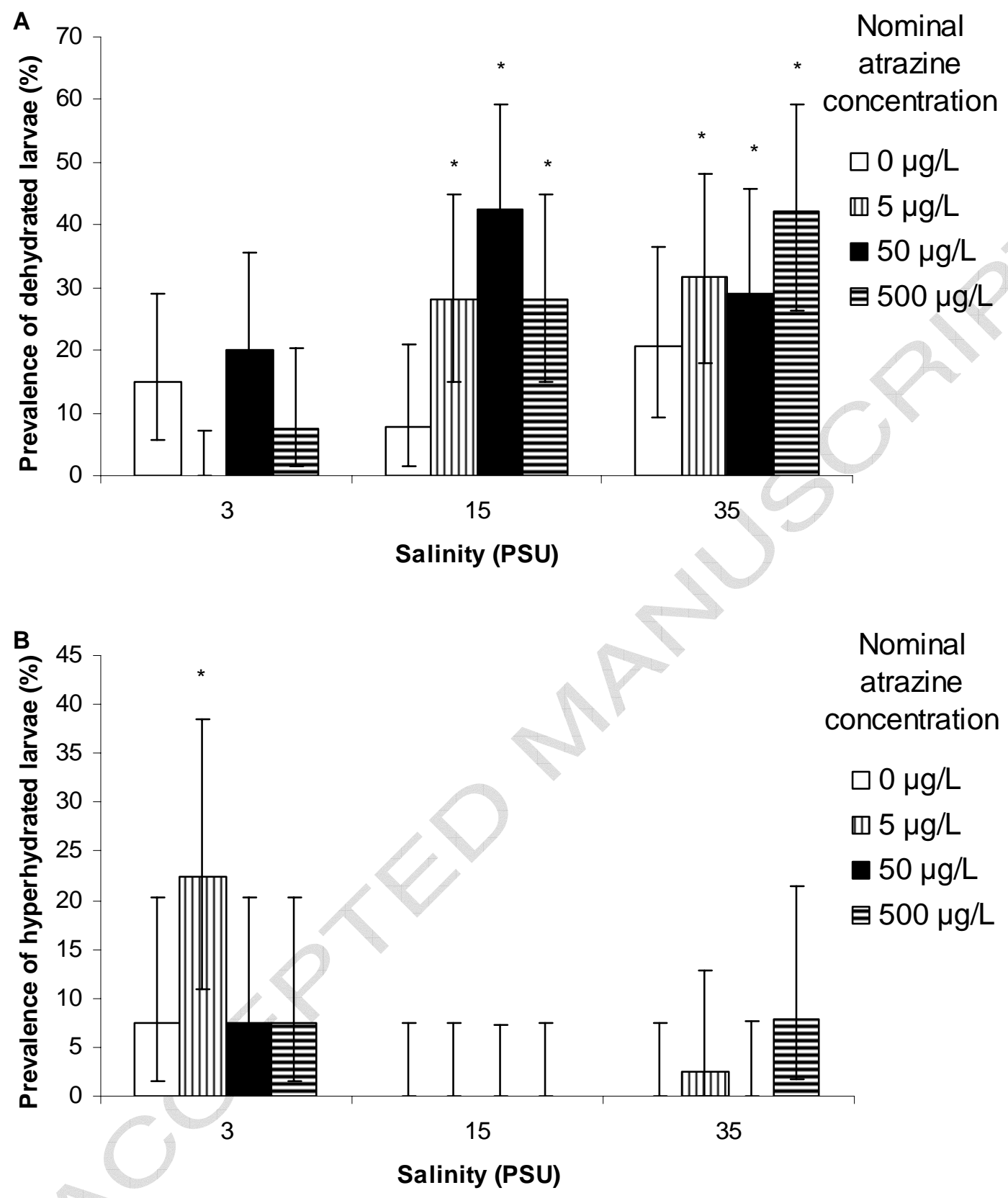
Fig. 2

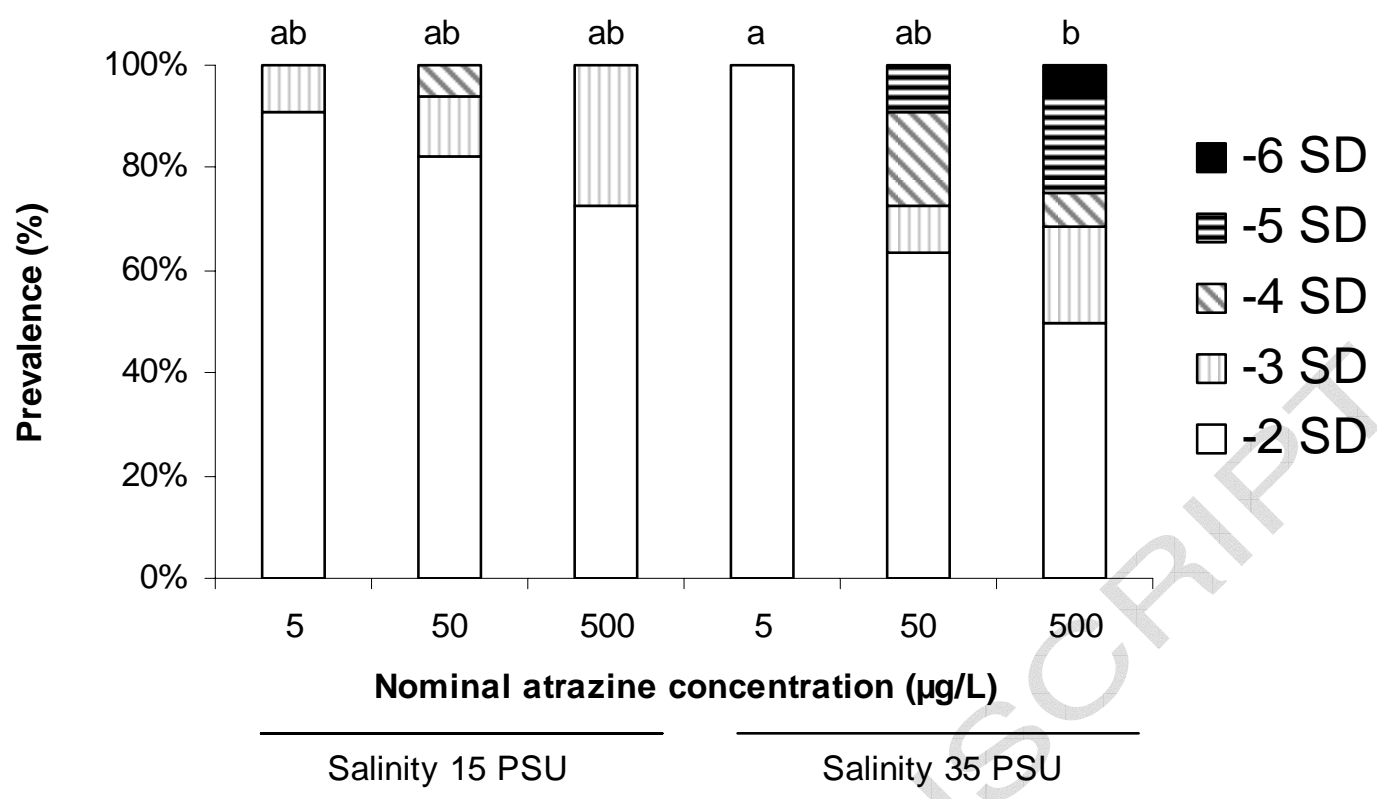

